JOURNAL OF CORPORATE RESPONSIBILITY

AND LEADERSHIP

The Challenges of Contemporary Management

IN THE GLOBAL ECONOMY

\title{
Creating Competitiveness of Peripheral Areas: The Study of Poland's Eastern Border Regions
}

DOI: http://dx.doi.org/10.12775/JCRL.2017.011

\author{
Arkadiusz Malkowski \\ West Pomeranian University of Technology in Szczecin \\ e-mail: amalkowski@zut.edu.pl
}

\begin{abstract}
Purpose: The purpose of this paper is to study changes in border areas in the context of globalisation and the increasing interregional competition. The article focuses on theoretical reflections on the creation of competitiveness of a border region and the role of human capital and innovativeness in the creation of this competitiveness.

Design / methodology / approach: The study is based on desk research. The analysis of available documents and data allowing to collect information on the eastern borderland of Poland has been conducted.

Findings: The hitherto model of the development of the east border region of Poland does not contribute to the creation of competitiveness of this region.
\end{abstract}

Research and practical limitations/implications: The study is theoretical and empirical in character. Results of the analyses should be used in the debate on the directions of development of the eastern border area of Poland.

Originality/value: The article points to the ineffectiveness of actions undertaken to improve the competitiveness of eastern borderland of Poland.

Paper type: theoretical article.

Keywords: border areas, glocalization, human capital, regional competitiveness, EU's eastern border. 


\section{Introduction}

The contemporary world economy is dominated by two complementary processes. On the one hand, there is progressive globalisation which impacts the increased importance of international exchange in the development of states. On the other hand, what should be noted, there are observed the processes of regionalization which increase the importance of regions not only on a national, but also on a global scale. The analysis of the processes of regionalization and globalisation cannot be conducted without taking into consideration the economic, political, and social conditions which have a significant impact on the regions. In the modern world, the regions become main beneficiaries of the globalisation and regionalization processes. It is often on the regional level that these processes are ultimately formed, and regional authorities decide on their scope.

The development of international trade and the accompanying globalisation process require analysing the role of particular regions in the global exchange process from a new perspective. The growth of international competition, free access to many markets, the possibility of free transfer of capital, technology and workforce create brand new conditions for the functioning of regional structures. The result of these changes is the increasing competition between regions which more and more often seek chances for their own economic development by increasing international competitiveness. Creating a competitive region in the twenty-first century is a difficult task which requires substantial funds. At the same time, it is hard to find an alternative to actions aiming at increasing the innovativeness of regions, and - as a result - their competitiveness. This article discusses some aspects of the process of creating a competitive region on the example of Eastern Poland. The study is based on the desk research. The analysis of available documents and data allowing to collect information on the eastern borderland has been conducted. Eastern Poland is an area encompassing four provinces: Lubelskie, Podkarpackie, Podlaskie, and Warmińsko-Mazurskie. They are border provinces, forming the eastern border of Poland and the EU. Due to its geopolitical position and socio-economic situation, the area should be considered very interesting in terms of research. 


\section{Glocalization of global processes}

When studying globalisation processes and their impact on particular regions, more and more often we speak of the so called glocalization (Guziejewska, 2008, pp. 5-14). The glocalization process seems to be inextricably linked to globalisation and regionalization, and results from numerous disputes over the perception of what is global and what is local. It consists in implementing and adjusting trends, services, values, and products which are global in character to local economic and social conditions. It applies also to regions themselves. In order to exist on the global market, they have to continuously build their competitive advantages not only locally, but also internationally. In this situation, it is very often crucial to take advantage of unique resources which will allow to reach particular goals (Kuciński, 2015, pp. 9-19). It seems that globalisation and regionalization naturally complement each other and are closely related (Breslin, Hughes, Phillips and Rosamond, 2003). Regionalization is a path to globalisation, and globalisation is a chance for the regions to intensify their development (MacLeod, 2001, pp. 804-829). In a special way, this concerns border areas. They are specific due to their regional character as well as their international dimension resulting from their cross-border character. For years treated as peripheral, they now construct their social and economic identity. After years of marginalization, they are becoming areas of accelerated socio-economic development (Malkowski, 2016, pp. 79-86).

Globalisation is a process which brings forward new chances and challenges for border regions. Globalisation is perceived as an ever increasing development of trade and socio-economic links on a global level, and at the same time a process of popularization of particular patterns or even unification of more and more areas of our life. According to Dicken, globalisation is a more complex and higher in quality form of internationalization. It means an intensification of links between states, but also a geographical expansion of activity and a clear functional integration of the main subjects of globalisation, i.e. enterprises distributed organisationally on an international scale (Zorska 1998, p. 19). It is this organisational distribution that could potentially become a factor in the development of border areas, thanks to their location which naturally combines two or more markets. Border areas become an attractive spot for investments. A traditional economy model based mainly on agriculture is being replaced more and more often by a more modern structure 
in which services, industry, or modern agriculture and processing play important roles.

\section{Development of border areas}

The stimulus behind the globalisation processes is undoubtedly the pursuit of improving the level of economic development, raising consumption or enrichment of individuals and entire societies. An entire border region can benefit from these favourable processes as long as it finds its place in the increasingly globalised economy. It is a key to building the competitiveness of border regions on the basis of innovations, know-how, high-quality social capital, and efficient organisational and administrative structures.

The progressive globalisation of social, economic, and political relations influenced the new perception of border areas. For many decades, these areas have been considered problematic. The peripherality of border regions was a result of both geopolitical processes as well as decisions made on the level of state administration. The natural distance from decision-making centres and the accompanying impact on the regional policies of governments are characteristic of all border areas. The development of local self-government and democracy caused a change in perception of the issues faced by border areas. This caused an increased awareness of the fact that border regions require more attention and concrete actions, so that the results of their peripheralisation could be overcome as soon as possible (Malkowska, 2013, p. 354). New concepts of managing border areas emerged. Attention was drawn to the role of institutional forms of cross-border cooperation in the development of the regions (Malkowska, 2015). The globalisation processes alone do not have to translate into the success of border areas. On the contrary, many authors indicate that those regions are specifically vulnerable to peripheralization, deepened by the globalisation and integration processes (Rykiel, 2000, pp. 36-46).

The essence of globalisation is often reduced to a process leading to diminishing of the role of state in the economy (Gereffi, 1989, pp. 92-104). This, of course, prompts a question as to whether the hitherto role of the state will not be taken over somehow by regional governments. It is fully in line with the concept of regional federation, the so called 'Europe of Fatherlands', promoted in Europe. The beginnings of 
this notion can be found in the processes taking place in the borderland. The will to oppose the division of Europe was the driving force behind the creation of the first Euroregions. They were supposed to blur the boundaries - 'the scars of history' - between nations and build a common European identity. A strong regional self-government was to be a counterweight for governments. In a special way it concerned peripheral regions which could not count on the central authorities to pay attention to their problems. A regional approach pointed to the experiences of the areas which were evolving dynamically owing to a thoroughly planned policy on a regional level. In other areas, the lack of strategy and consistency in the activities of territorial authorities resulted in a lower level of economic development, and often in stagnation if not recession.

In the literature of the subject, there are opinions according to which strong regions may become and are, in fact, becoming one of the issues of the modern world. Excessive regionalization - i.e. closing of developed countries, regional islands of prosperity surrounded by 'golden walls' - leads to increasing disparities on a global scale. It is also the cause of destruction of the integration processes, or the so called globalophobia. Globalophobia is defined as an irrational fear of integration with the world. In this context, globalisation is perceived as a threat to the political, economic, and social sovereignty (Castillo, 2003, pp. 77-82). Such an approach is usually presented by authors describing the situation of third-world countries in the context of globalisation. It draws attention to an essential feature of globalisation processes: their complexity and multidimensionality. This significantly limits the possibility of unambiguously defining both its positive and negative impact on the integration processes on a global or regional scale.

It seems, however, that regionalization, or at least its European dimension, can be treated as the desire to preserve some elements of autonomy, and thus opposing the globalisation tendencies. Regionalization is a process which can and should be used to overcome the problems of peripheral regions.

\section{Human capital in the creation of competitiveness of a border region}

Competitiveness of a border region is its capacity to compete on a regional and global scale. It is constructed on many levels. According to the European Commission, competitiveness is based on the 
capacity to produce goods and services which have won acceptance on the international market while at the same time maintaining a high level of income (European Commission, 1999). In accordance with the definition proposed by OECD, competitiveness is the degree to which one country (region), in conditions of free trade and free market, can produce goods and services accepted by international markets, while at the same ensuring an actual long-term income growth for the population (OECD, 1996). Competitiveness is an individual feature of a given cross-border unit which defines its capacity to create conditions for a permanent and balanced socio-economic development in the conditions of global competition. Among the factors which can contribute to creating competitiveness of peripheral regions, the most often mentioned are: innovation, competitiveness, globalisation, human and social capital. In the concept of the development of border regions, the essential element is a person with an appropriate level of knowledge and skills. Human capital is a carrier of technological knowledge which is the foundation of scientific and technological progress. This capital creates new technologies, develops the existing technical and organisational solutions. It is the basic factor of local and global development. Human capital is one of the main factors influencing location decisions made by foreign investors. The flow of new technologies or capital is possible thanks to investment decisions of large transnational corporations, and small and medium enterprises seeking new markets. The mobility of human capital is the stimulus of globalisation and glocalization processes.

Unique employee qualifications determine the attractiveness of a worker on the global job market, but also the attractiveness of particular territorial arrangements, including the border areas. A cheap and well-qualified workforce is important. The basis of the economies in the most developed countries are the knowledge-intensive branches of economy. This clearly indicates the role of human capital in modern economy. The key endogenous resource of the border regions are the human capital resources. From the perspective of peripheral regions, it is essential to skilfully shape and manage those resources. Pocztowski points out that managing human resources is a defined management concept, in which human resources are perceived as a component of organisational assets and the source of competitiveness (Pocztowski, 2003, pp. 36-37).

According to the European Commission, competitiveness is based on the capacity to produce goods and services which have won acceptance on the international market, while maintaining a high level of 
income (European Commission, 1999). Especially in the case of services, we are dealing with the role of the human capital in the creation of a competitive service offer. According to Klasik, competitiveness means an advantage over other regions, which is a result of the attractiveness of the service offer addressed to the current and potential users of the region - inhabitants, companies, investors, guests. Its source is a modern material, institutional and intellectual infrastructure of the region (Klasik, 2001, pp. 99-100). Others point out that a competitive region is characterized by creating and offering all available possibilities and perspectives for a constant development to any interested parties (Meyer and Milewski, 2009, p. 20; Hernik, 2014, pp. 70-76). The concept of creating a competitive region should assume the creation of a web of connections encompassing the society, enterprises, research institutions, and the public and local administration.

Creating a competitive border region depends mostly on comparative advantage. Comparative advantage is a result of possessing particular and often unique resources, including primarily human resources, knowledge and innovation resources, as well as a level of development of social and technical infrastructure, and natural resources. No less important from the point of view of creating the competitiveness of a region is the skill of alternative use of indicated and limited resources. Creating a competitive region is extremely important in the age of globalisation. The competitive pressure increases not only on the producers of market goods but also on the quality of the spatial-economic environment in which these producers operate.

One of the elements of creating the competitiveness of the eastern border region will undoubtedly be all the operations connected with communicating with the external environment. This communication includes transferring information on the economic, tourist, cultural, and innovative advantages of the region, and convincing both the external and internal consumers that the offer of the east borderland is more attractive than other offers. It is no less essential to ensure the development of social and innovative potential of the region.

\section{The issue of competitiveness of the east borderland areas}

The region of Eastern Poland encompasses 31.6\% of the country's total area. In 2014, eastern provinces were inhabited by over 8 million people. 
The population density in this area is lower than the national average. There are 83 persons per $1 \mathrm{~km}^{2}$, while the national average is 123.2 persons per $1 \mathrm{~km}^{2}$. While determining the peripherality of a region, what is often mentioned is its insufficient economic development. The scope of economic peripherality is an important element of research conducted in the border regions (Malkowski, 2013, pp. 513-522).

As predicted by Rykiel, the border regions in Poland became participants in two opposing processes - integration and isolation (Rykiel, 2000, p. 35). On the one hand, the western border has been a place of animated cross-border contacts since 1991. On the other hand, as part of the same process of European integration, a new 'golden curtain' began to emerge, this time economic and political rather than ideological in character, separating the communities of Eastern Europe from the prosperous states of the integrating European Union. The growth of administrative barriers and the inconvenience of restrictive border controls on the outer borders of the EU were most felt by the residents of the eastern borderland area. Lively border economic contacts with the Kaliningrad Oblast, Belarus or Ukraine, perceived as a factor conducive to the development of this region's competitiveness, have been largely hampered. The introduction of visas, limiting the scarce border movement, negatively impacted the socio-economic situation of Poland's eastern regions.

One of the measures determining the economic power of a region is its GDP per capita. As an aggregated measure of the value of goods and services produced in a given region, it is often used in research on the level of development of border areas. It usually turns out that the productivity of the border regions' economies is lower than in the core areas. This dependence, confirmed by studies on numerous borderlands, is also applicable in the case of Poland's eastern borderland (cf. Table 1).

Table 1. GDP per capita in Polish provinces in 2008-2014

\begin{tabular}{lllll}
\hline Province & \multicolumn{4}{l}{ GDP per capita [PLN] } \\
\cline { 2 - 5 } & $\mathbf{2 0 0 8}$ & $\mathbf{2 0 1 0}$ & $\mathbf{2 0 1 2}$ & $\mathbf{2 0 1 4}$ \\
\hline Poland & 33,511 & 37,524 & 42,285 & 44,686 \\
\hline Łódzkie & 31,193 & 34,747 & 39,402 & 41,839 \\
\hline Mazowieckie & 51,120 & 59,666 & 67,388 & 71,659 \\
\hline Małopolskie & 30,046 & 32,909 & 37,334 & 39,834 \\
\hline
\end{tabular}


Table 1. continued

\begin{tabular}{|c|c|c|c|c|}
\hline \multirow[t]{2}{*}{ Province } & \multicolumn{4}{|c|}{ GDP per capita [PLN] } \\
\hline & 2008 & 2010 & 2012 & 2014 \\
\hline Śląskie & 35,939 & 40,201 & 44,863 & 46,499 \\
\hline Lubelskie & 23,830 & 25,875 & 29,639 & 31,170 \\
\hline Podkarpackie & 24,019 & 26,122 & 29,553 & 31,642 \\
\hline Podlaskie & 24,428 & 27,381 & 30,288 & 32,350 \\
\hline Świętokrzyskie & 27,615 & 28,968 & 31,642 & 32,640 \\
\hline Lubuskie & 29,106 & 31,723 & 35,078 & 37,635 \\
\hline Wielkopolskie & 35,449 & 39,454 & 44,773 & 47,992 \\
\hline $\begin{array}{l}\text { Zachodniopomor- } \\
\text { skie }\end{array}$ & 30,040 & 32,061 & 35,453 & 37,461 \\
\hline Dolnośląskie & 36,239 & 42,295 & 47,986 & 50,031 \\
\hline Opolskie & 28,869 & 30,818 & 34,152 & 36,299 \\
\hline $\begin{array}{l}\text { Kujawsko-Pomor- } \\
\text { skie }\end{array}$ & 28,784 & 31,127 & 34,365 & 36,379 \\
\hline Pomorskie & 32,050 & 36,017 & 41,341 & 42,558 \\
\hline $\begin{array}{l}\text { Warmińsko-Ma- } \\
\text { zurskie }\end{array}$ & 24,702 & 27,197 & 30,232 & 31,955 \\
\hline
\end{tabular}

Source: own study on the basis of data from GUS (Main Statistical Office).

All regions of the eastern borderland (bolded in Table 1) are characterized by the lowest GDP per capita in the country. Its level is twice as low as in the Mazowieckie province. Despite the geographical proximity to the Mazowieckie province, the polarization of the socio-economic development levels is clearly visible. The primary beneficiary of the integration processes is the Mazowieckie province with the agglomeration of Warsaw, which caused the draining of the job market in the eastern provinces and a mass migration of young people. Allowing people to seek job opportunities in European countries deepened that process even further. A large number of young and educated residents of the borderland left Poland and went to the UK, France, Belgium, and the Netherlands. The rural character of the region, lack of attractive job offers, and scarce interest of foreign investors in the region all resulted in the deterioration of the socio-economic situation of the entire region. It was necessary to take measures aiming at creating conditions in which the peripheral area of the eastern borderland could build its competitiveness. 
The demographic processes characterised by, among others, a decrease in the number of births and marriages, delaying the average age of childbirth and forming relationships, an increase in the number of divorces and informal relationships, are global in character and find their reflection also in the area of the eastern borderland. According to prognoses prepared by the Main Statistical Office (GUS), by the year 2050 the population of the eastern borderland area will decrease by over 1.5 million people (Table 2). At the same time, the percentage of population in a non-productive age will increase, which will reflect in the demographic load index of these areas.

Table 2. Changes in the size of population in Poland's eastern borderland in the years 2013-2050

\begin{tabular}{lccc}
\hline \multirow{2}{*}{ Province } & \multicolumn{2}{c}{ Number of residents in thousands } & \\
\cline { 2 - 4 } & $\mathbf{2 0 1 3}$ & $\mathbf{2 0 5 0}$ & Change \\
\hline Warmińsko-Mazurskie & 1446.9 & 1207.9 & -239.0 \\
\hline Podlaskie & 1194.9 & 982.3 & -212.6 \\
\hline Lubelskie & 2156.1 & 1710.6 & -445.5 \\
\hline Podkarpackie & 2129.3 & 1870.3 & -259.0 \\
\hline Mazowieckie & 5316.8 & 5318.7 & 1.9 \\
\hline
\end{tabular}

Source: own study based on data of GUS (Main Statistical Office).

The only province which will maintain its number of residents is the Mazowieckie province. According to GUS data, the number of people in this region is expected to grow by almost 2,000 people and amount to over 5 million.

The indicator of a region's wealth is GDP per capita, increasingly used in economic research. Assuming that the wealth of the region's residents is strictly correlated with competitive goods and services offered by the region, it can be stated that GDP per capita can also often reflect the competitiveness of the region in relation to other regions. Although this indicator is not perfect, as it does not take into account many economic phenomena, it also has its advantages. Primarily, it takes into consideration the number of residents, it is comparable in time and relatively easy to calculate.

The analysis of changes in GDP per capita in 2008-2014 (Table 3) presents the difficult situation of the eastern borderland. In 2008, the 
Warmińsko-Mazurskie province was in the best position, with GDP per capita equating $73 \%$ of the national average. The position of the Lubelskie province was the worst, with GDP per capita equal to only $71 \%$ of the national average. All the regions of the eastern borderland were among the least developed areas of Poland.

Table 3. Changes in GDP per capita in 2008-2014

\begin{tabular}{lcccc}
\hline \multirow{2}{*}{ Province } & GDP per capita, Poland $=\mathbf{1 0 0}[\%]$ & \\
\cline { 2 - 5 } & $\mathbf{2 0 0 8}$ & $\mathbf{2 0 1 0}$ & $\mathbf{2 0 1 2}$ & $\mathbf{2 0 1 4}$ \\
\hline Poland & 100.0 & 100.0 & 100.0 & 100.0 \\
\hline Łódzkie & 93.1 & 92.6 & 93.2 & 93.6 \\
\hline Mazowieckie & 152.5 & 159.0 & 159.4 & 160.4 \\
\hline Małopolskie & 89.7 & 87.7 & 88.3 & 89.1 \\
\hline Śląskie & 107.2 & 107.1 & 106.1 & 104.1 \\
\hline Lubelskie & 71.1 & 69.0 & 70.1 & 69.8 \\
\hline Podkarpackie & 71.7 & 69.6 & 69.9 & 70.8 \\
\hline Podlaskie & 72.9 & 73.0 & 71.6 & 72.4 \\
\hline Świętokrzyskie & 82.4 & 77.2 & 74.8 & 73.0 \\
\hline Lubuskie & 86.9 & 84.5 & 83.0 & 84.2 \\
\hline Wielkopolskie & 105.8 & 105.1 & 105.9 & 107.4 \\
\hline Zachodniopomorskie & 89.6 & 85.4 & 83.8 & 83.8 \\
\hline Dolnośląskie & 108.1 & 112.7 & 113.5 & 112.0 \\
\hline Opolskie & 86.1 & 82.1 & 80.8 & 81.2 \\
\hline Kujawsko-Pomorskie & 85.9 & 83.0 & 81.3 & 81.4 \\
\hline Pomorskie & 95.6 & 96.0 & 97.8 & 95.2 \\
\hline Warmińsko-Mazurskie & 73.7 & 72.5 & 71.5 & 71.5 \\
\hline
\end{tabular}

Source: own study on the basis of data from GUS (Main Statistical Office).

In 2014 compared to 2008, the situation of the eastern borderland areas further deteriorated. Despite spending substantial sums from EU subsidies as a part of provinces' operational programs and additional support from the Operation Program Development of Eastern Poland (Polish: PO RPW) in 2007-2013 the value of GDP per capita in comparison with the national average decreased (Table 3.)

Although the main goal of the aforementioned programme was to inhibit the stagnant tendencies deciding about the marginalization and 
peripheralization of the provinces of Eastern Poland and stimulating growth factors in these provinces, the program did not contribute to solving the problems nor to alleviating their effects. In the case of the Lubelskie province, GDP per capita in 2014 is less than 70\% of the national average, which means a decrease in comparison with 2008. Similarly in the case of the Warmińsko-Mazurskie province we can observe a decrease in GDP per capita by over 2 percentage points.

In accordance with the premises of PO RPW, the scope of the program's intervention was to encompass issues concerning the creation of a modern economy, support of provincial growth centres, transportation infrastructure, increasing the tourist attractiveness of the Eastern Poland, and technical assistance. The impulse for the creation of modern economy were supposed to be enterprises related to, among others, the development of university infrastructure, supporting innovations, economic promotion and cooperation, recapitalization of venture capital funds, as well as extension of the infrastructure of information society. Moreover, support was given to projects concerning road infrastructure, bike paths, and tourist promotion (PO RPW, 2007, p. 5). For the implementation of the PO RPW in 2007-2013, € 2,809.07 million was guaranteed, including: from the EU funds (European Regional Development Fund ERDF) - $€ 2,387.71$ million; from the public national funds - about $€ 421.36$ million.

Table 4. The structure of using EU funds until 2014

\begin{tabular}{lcc}
\hline Area & Eastern Poland & Poland \\
\hline Innovations and enterprise & $16 \%$ & $17 \%$ \\
\hline Transportation & $41 \%$ & $37 \%$ \\
\hline Environmental protection & $7 \%$ & $14 \%$ \\
\hline Job market, human capital & $14 \%$ & $12 \%$ \\
\hline Culture and tourism & $3 \%$ & $3 \%$ \\
\hline Energy industry & $4 \%$ & $4 \%$ \\
\hline Information society & $5 \%$ & $4 \%$ \\
\hline Social infrastructure and revitalization & $8 \%$ & $6 \%$ \\
\hline
\end{tabular}

Source: own study.

The analysis of the structure of using the funds by the eastern borderland area indicates that it does not differ significantly from the 
national average. This should be regarded as an error. Creating the competitiveness of a border region requires a concentration of outlays on innovations and enterprises or the job market. In the cases of outlays on innovations and enterprises, in the provinces of eastern Poland a smaller percentage of funds was spent than the average for the entire country. In the case of the job market and human capital, in the eastern region the expenses were bigger by two percentage points than the national average, but in regions which are supposed to quickly build their competitiveness in relation to other areas of Poland, these values are still too small.

\section{Conclusions}

The reflections presented in the article are only a contribution to the debate on the issue of creating a competitive region of the eastern borderland. An overview of the literature of the subject indicates that creating competitiveness on a regional scale is a very important issue both on a national scale as well for the entire European Union. The future of peripheral regions in the globalised world economy requires a creation of an integrated competitive product. This in turn requires a concentration of financial outlays and a thoughtout regional policy. In order to build their competitive advantage, the peripheral regions need to invest in areas which are key for socio-economic development:

- increased innovativeness;

- development of the R\&D sector;

- strengthening of human capital;

- increased entrepreneurship.

However, actions aiming at obtaining an adequate support scale and selecting projects which would allow to achieve a synergy effect are indispensable to contribute to the increase in competitiveness.

It is difficult to expect spectacular successes while implementing a structural policy similar to that of other regions. The example of the eastern borderland areas indicates that spending substantial sums on investments does not guarantee increased competitiveness. It seems that only a concentration of outlays and a careful selection of supported projects can provide a better use of opportunities provided by new structural funds. It is necessary to take actions to change the 
concept of the development of the eastern borderland area. The eastern borderland of Poland is at the start of the process of building its competitiveness. As a consequence of the failure to create competitiveness of the region, it will be marginalized.

\section{References}

Breslin, S., Hughes, C.W., Phillips, N., Rosamond, B. (Eds.) (2003), New Regionalism in the Global Political Economy: Theories and Cases, Routledge.

Castillo, G.A. (2003), “Respondiendo preguntas sobre la globalización”, Gestión en el Tercer Milenio, Vol. 5, No. 10, pp. 77-82.

European Commission (1999), Sixth Periodic Report on the Social and Economic Situation of Regions in the EU.

Gereffi, G. (1989), "Development Factories and the Global Factory”, Annals of the American Academy of Political and Social Science, 1989, No. 525, pp. 92-104.

Guziejewska, B. (2008), “Glokalizacja - oksymoron czy wyzwanie dla samorządu terytorialnego?”, Samorzq̨d Terytorialny, No. 7-8, pp. 5-14.

Hernik, J. (2014), “Turystyczna konkurencyjność miasta - determinanty”, Marketing i Rynek, No. 10 (CD), pp. 70-76.

Klasik, A., "Konkurencyjność województwa śląskiego na tle innych regionów: Ujęcie syntetyczne”, in: Województwo Ślq̨skie: Integracja, konkurencyjność, nowe inicjatywy, II Śląskie Forum Rozwoju Lokalnego i Regionalnego, Akademia Ekonomiczna i Górnośląska Wyższa Szkota Przedsiębiorczości im. K. Goduli, Katowice 2001, pp. 31-38.

Kuciński, K. (2015), “Glokalizacja a zarządzanie”, Kwartalnik Nauk o Przedsiębiorstwie, No. 3, pp. 9-19.

MacLeod, G. (2001), “New Regionalism Reconsidered: Globalisation and the Remaking of Political Economic Space”, International Journal of Urban and Regional Research, Vol. 25, Issue 4, pp. 804-829.

Malkowska, A. (2013), "Strategia rozwoju euroregionu Pomerania a budowa konkurencyjnego regionu przygranicznego”, Prace Naukowe Uniwersytetu Ekonomicznego we Wrocławiu, No. 307, pp. 353-362.

Malkowska, A. (2015), “Wybrane aspekty funkcjonowania Euroregionu Pomerania”, Zeszyty Naukowe Uniwersytetu Szczecińskiego: Współczesne Problemy Ekonomiczne: Globalizacja, Liberalizacja, Etyka, No. 10, pp. 23-31.

Malkowski, A., (2013), "Rola zarządzania strategicznego w budowaniu konkurencyjnego regionu transgranicznego na przykładzie Programu Operacyjnego Współpracy Transgranicznej Republika Czeska-Rzeczpospolita Polska 2007-2013”, Prace Naukowe Uniwersytetu Ekonomicznego we Wrocławiu, Issue 315, pp. 513-522.

Malkowski, A. (2016), “Assessment of Border Region Development Based on the Case Study of the Lubusz Voivodeship”, Folia Pomeranae Universitatis Technologiae Stetinensis: Oeconomica, No. 331(85)4, pp. 79-86.

Meyer, B., Milewski, D. (Eds.) (2009), Strategie rozwoju turystyki w regionie, PWN, Warszawa.

OECD (1996), Industrial Structure Statistics 1994, Paris. 
Pocztowski, A. (2003), Zarzq̨dzanie zasobami ludzkimi: Strategie, procesy, metody, PWE, Warszawa.

PO RPW (2007), Program Operacyjny Rozwój Polski Wschodniej 2007-2013, Ministerstwo Rozwoju Regionalnego, Warszawa.

Rykiel, Z. (2000), “Globalizacja, unionizacja i regionalizacja polskiej przestrzeni”, Studia Regionalne i Lokalne, No. 1, pp. 35-46.

Zorska, A. (1998), Ku globalizacji: Przemiany w korporacjach transnarodowych i gospodarce światowej, PWN, Warszawa. 
